\title{
Миннегалиев P.T. \\ Правовая природа и основания отказа в государственной регистрации при создании юридического лица
}

Набережночелнинский филиал ЧОУ ВО «Казанский инноваџионный университет им. В.Г. Тимирясова (ИЭУП)»

doi: $10.18411 / l j-31-01-2018-37$

(Россия, Набережные Челнь)

idsp: 000001:lj-31-01-2018-37

С точки зрения теории государственного управления отказ в государственной регистрации является для регистрирующих органов одним из видов управленческого решения в отношении объекта управления - регистрируемого юридического лица. Данное воздействие - явление субъективное, и его применение напрямую зависит от содержания документов, поданных на регистрацию конкретным заявителем. Процесс выработки и принятия решения об отказе в государственной регистрации в этом случае ничем не отличается от процедуры принятия решения о регистрации юридического лица.

Отказом в государственной регистрации при создании юридического лица следует считать юридический акт регистрирующего органа, на основании которого правоспособность юридического лица не возникает и юридическое лицо не считается созданным. Отказ в государственной регистрации при регистрации изменений учредительных документов следует считать юридический акт, на основании которого юридическая сила изменений, внесенных в учредительные документы, будет ничтожна для третьих лиц. Отказ в государственной регистрации при регистрации прекращения существования юридического лица в результате завершения его ликвидации будет являться юридическим актом, на основании которого юридическое лицо сохраняет свою правоспособность, а регистрация не будет считаться завершенной.

Для заявителя, таким образом, отказ в государственной регистрации будет являться санкцией за нарушения, перечень которых содержится в законе. Если заявитель посчитает, что мотивы отказа в государственной регистрации не могут служить причиной для вынесения такого решения, то ему дается право подать иск в суд на регистрирующий орган.

Отказ допускается только по формальным признакам:

a) в случае отсутствия в числе представленных на регистрацию документов одного или нескольких таких документов, необходимых для государственной регистрации;

б) в случае представления документов в ненадлежащий регистрирующий орган. Данная ситуация возможна, если заявление подано в тот орган, на территории регистрационного округа которого не располагается: постоянно действующий исполнительный орган юридического лица; иной орган юридического лица; место постоянного проживания лица, имеющего право действовать от имени юридического лица без доверенности.

Орган государственной регистрации также может быть признан ненадлежащим, если регистрируемое лицо относится к тем отдельным видам юридических лиц, для которых установлен специальный порядок регистрации, включающий в себя регистрацию в специализированных органах.

Дополнительно установлены случаи, когда также не допускается регистрация создания юридического лица или регистрация изменений, вносимых в учредительные документы юридического лица. Речь идет о нормах п. 2 ст. 20 Закона «О государственной регистрации юридических лиц и индивидуальных предпринимателей», где предусмотрено ограничение правоспособности юридических лиц, находящихся в процессе ликвидации. Регистрирующий орган в этой ситуации поставлен в ситуацию «между двух огней». С одной стороны, ему нельзя производить указанные регистрационные действия, а с другой - п. 2 ст. 23 четко указывает, что мотивы отказа в регистрации могут содержаться только в п. 1 этой же статьи и нигде более. 
К сожалению, данным Законом не предусмотрена возможность приостановления регистрации по просьбе заявителя. Это позволило бы заявителям избежать отказов в регистрации по причинам, носящим формальный характер и технически легко устранимым.

Также предусмотрено, что решение об отказе в государственной регистрации должно быть принято не позднее срока, установленного ст. 8 Закона «О государственной регистрации юридических лиц и индивидуальных предпринимателей». Данный срок исчисляется с даты подачи документов в регистрирующий орган и должен составлять не более пяти рабочих дней, как и в случае, когда принимается решение о проведении государственной регистрации. Пятидневный срок - это небольшой срок, если осуществлять процедуру государственной регистрации в том виде, в котором она предусмотрена ст. 51 ГК РФ, т.е. когда регистратору необходимо проверить содержание всех документов на их соответствие закону и установить нарушения установленного законом порядка образования юридического лица. С другой стороны, пятидневный срок это достаточно большой срок, если регистратор вправе пользоваться только теми мотивами отказа. Они носят предельно формальный характер и не нужно изучать содержание документов, чтобы отказать в регистрации. Для этого регистратору достаточно проверить наличие от двух до шести (в зависимости от вида регистрационного действия) документов и убедиться, что юридическое лицо обратилось в надлежащий орган - т.е. оно имеет место нахождения на территории его регистрационного округа.

К сожалению, не предусмотрена форма отказа в государственной регистрации, но, по всей видимости, это будет письменный документ, утвержденный уполномоченным должностным лицом регистрирующего органа (регистратором), подпись которого обязана скрепляться гербовой печатью данного органа.

В законе установлен способ, которым решение об отказе в государственной регистрации доводится до сведения юридического лица или его учредителей.

Данный отказ направляется лицу, указанному в заявлении о государственной регистрации, с уведомлением о вручении такого решения. По всей видимости, это может быть как почтовое отправление с уведомлением, так и выдача документа непосредственно лицу, указанному в заявлении о регистрации. Необходимо отметить, что в ст.ст. 12, 14, 17, 21 Закона «О государственной регистрации юридических лиц и индивидуальных предпринимателей», которые устанавливают требования к содержанию заявлений о регистрации, подобная информация не предусмотрена. При вынесении отказа в проведении государственной регистрации необходимо также учесть, что если сведения о регистрации отражаются в реестре, то отказ в ее проведении в реестре отражаться не может и в данном случае следует предусмотреть существование документа, где сведения об отказах могли бы систематизироваться, а документы, поданные на регистрацию, храниться.

Решение об отказе в государственной регистрации может быть обжаловано в судебном порядке. Основания иска, то есть обстоятельства, на которых заявитель в качестве истца основывает свое обращение в суд, должны быть названы в его заявлении в соответствии с п. 4 части 2 ст. 126 ГПК РФ. Значение в данном случае будут иметь только юридические факты, то есть обстоятельства, которые повлекли возникновение, изменение или прекращение правоотношений, с которыми связан возникший между сторонами заявителем и регистрирующим органом - материально-правовой спор.

$$
* * *
$$

1. Исмагилов Р.Ф., Курзенин Э.Б., Числов А.И. Правовое регулирование создания коммерческих организаций // Правовое поле современной экономики. - 2015. - № 9. - С. 96-112.

2. Чумакова О.В. Регистрация юридических лиц: проблемы и пути их разрешения // Законы России: опыт, анализ, практика. - 2008. - № 8. - С. 78-82.

3. Чуряев А.В. Государственная регистрация юридических лиц в России: отдельные аспекты // Адвокат. - 2012. - № 4. - C. 91-100.

4. Чуряев А.В. Отказ в государственной регистрации юридических лиц: перспективы правового регулирования // Право и экономика. - 2010. - № 4. - С. 22-26. 